\title{
Environmental Balance Management In Nonformal Education Learning
}

\author{
Abdul Rahmat ${ }^{1, *}$, Tulus Suryanto ${ }^{2}$, Supli Effendi Rahim ${ }^{3}$ \\ ${ }^{1}$ Gorontalo State University, Gorontalo, Indonesia \\ ${ }^{2}$ Raden Intan Islamic University, Lampung, Indonesia \\ ${ }^{3}$ Higher Education of Health Sciences BinaHusada, Palembang, South Sumatra, Indonesia
}

\begin{abstract}
This study aims to determine the direct effect of the learning environment on the learning outcomes about environmental balance, interest in learning on the results of learning about environmental balance, and learning environment learning to interest in learning. This research is a survey research using path analysis technique with the sample of research is student package C in SKB BonebolangoGorontalo 2016/2017 Lesson Year, which amounts to 60 people. There are three variables that are used as research objects, namely two exogenous variables that include learning environment and interest in learning and endogenous variable that is the result of learning about environmental balance. The results of the study indicate that: (a) there is a positive direct effect of the learning environment on the learning outcomes of environmental balance, (b) there is a direct positive influence of interest on the learning outcomes of environmental equilibrium, (c) there is a direct positive influence of the learning environment on learning interest, d) there is an indirect influence of the learning environment on learning outcomes through interest in learning.
\end{abstract}

\section{Page layout}

Learning as a process is influenced by several factors. As stated by the Syah (2012: 146), that "success in the learning process is influenced by two factors: internal factors (factors from within students), namely the state or condition of the students' physical and spiritual, interests and motivation and external factors (external factors students), ie environmental conditions around students. From the preliminary survey results it can be argued that the average learning outcomes on Environmental Balance are relatively low when compared with other materials.

This is due to the lack of interest in learning from students and also because of the condition of the learning environment in their poor schools. Uno [2], that learning is a process that produces behavioral changes done deliberately to gain knowledge, skills and new experiences towards the better. According to learning environment includes three components, namely family environment, school environment and community environment. So the learning environment is a condition where one can carry out the learning process.

Shah, learning is a processed activity and is a very phenomenal element in the conduct of each type and level of education [1]. Learning as a process allows one to change his behavior, Djamarah, suggests that learning is a series of activities of body and soul to obtain a change of behavior as a result of individual experience in interaction with the environment [3]. Environmental balance is the ability of the environment to overcome the pressure of nature and from human activities, and the ability of the environment in maintaining the stability of life in it. Environmental balance will be achieved when there is an interaction of organisms with environmental factors and intercomponents interactions in an environment can run proportionally [4].

Soemarwoto, explains that the environment is a space occupied by a living human being along with other living things (plants, animals, microorganisms), and inanimate objects, such as air composed of various gases, water in the form of steam, liquid and solid, soil, minerals in soil, rocks and fossils, which support each other to meet human needs.

Experts divide the learning environment into several kinds. Sartain in Purwanto, divides the environment into three parts, namely (1) external or physical environment, is everything that exists in this world that is not human, like humans, plants, water, climate, animals etc. (2) internal inveronment, is everything that has been included in us, which can affect our physical growth (3) social environment, is all other people or humans that affect us.

To be able to see the success of the process of teaching and learning activities, all factors related to teachers and students must be considered. This interest

\footnotetext{
* Corresponding author: abdulrahmat $@$ ung.ac.id
} 
in students is one of the signs of interest. According to the Shah, interest (interest) means a high tendency and excitement or a great desire for something [1]. The same thing is also expressed by Slameto, that interest is a sense of preference and a sense of attachment to a thing or activity, without anyone telling [5]. The same opinion by Winkel, says that interest is the tendency of sedentary subjects, to appeal to a particular field of study or subject and to feel good about learning the material.

\section{Research Methods}

The study was conducted within 2 months from April to May 2017. Type of research used in this study is a survey by using Path Analysis. Target population is all students of package $\mathrm{C}$ in SKB BonebolangoGorontalo Lesson Year 2016/2017. Testing the validity of grains of learning results about environmental balance using the formula biserial correlation is the correlation between the test score score with the total test score [6].

\section{Results and Discussion}

\subsection{Learning Outcomes of Environmental Balance (Y)}

Average score $(\bar{Y})$ is 9,467 ; median (Me) of 14,630 ; mode (Mo) of 14,891; and standard deviation (SD) of 2,456 . Calculation results can be seen in the appendix. If the price of mode (Mo), median (Me) and average $(\bar{Y})$, then based on the assessment of the norm norm score of learning result of environmental balance of students tend to be high.

\subsection{Learning Environment (X1)}

Average score $\left(\overline{X_{1}}\right)$ was 84,$800 ;$ median $(\mathrm{Me})$ of 85,804; mode (Mo) of 86.833; and standard deviation (SD) of 13,097. Calculation results can be seen in the appendix. If the price of mode (Mo), median (Me) and average $\left(\overline{X_{1}}\right)$, then based on the assessment of the norm norm score of student learning environment tends to be high.

\subsection{Interest to learn}

Average score $\left(\overline{X_{2}}\right)$ was 89,800 ; median (Me) of 89.260; mode (Mo) of 88.409; and standard deviation (SD) of 12,291. Calculation results can be seen in the appendix. If the price of the mode (Mo), median (Me) and the average $\left(\overline{X_{2}}\right)$, then based on the assessment of the norm reference score of student learning interest tend to be normal.

The coefficient of the learning environment pathway to learning interest is similar to the relationship between learning interest and the learning environment. The value of the path coefficient as output is in Table 1.

Table 1. Correlations

\begin{tabular}{|c|c|c|c|}
\hline \multirow{2}{*}{} & Learning Environment & Interest to learn \\
\hline \multirow{3}{*}{ Learning Environment } & Pearson Correlation & 1 & $.930^{* *}$ \\
\cline { 2 - 4 } & Sig. (2-tailed) & 60 & .000 \\
\cline { 2 - 4 } & $\mathrm{N}$ & $.930^{* *}$ & 60 \\
\hline \multirow{3}{*}{ Interest to learn } & Pearson Correlation & .000 & 1 \\
\cline { 2 - 4 } & Sig. (2-tailed) & 60 & 60 \\
\cline { 2 - 4 } & $\mathrm{N}$ & & \\
\hline \multirow{2}{*}{$* *$ Correlation is significant at the 0.01 level (2-tailed). }
\end{tabular}

From Table 1 obtained correlation coefficient $r_{12}=$ 0,930 . The value of correlation coefficient is also the value of the coefficient path. Test significance correlation coefficient obtained Sig value. (2-tailed) 0.000.Karena two-party test then the value of Sig must be divided 2. The division by two obtained 0,000 . Because the value of Sig. $=0,000<0.050$ then the correlation coefficient (path coefficient) interest in learning with learning environment significant (meaningful).

\section{Conclusions}

The result of learning about the balance of the student environment is directly influenced by the positive learning environment. This means that the more conducive the student learning environment the higher the achievement of their learning results about the material of environmental balance. Results of learning about the environmental balance of students are directly influenced by the positive interest in learning. This means that the higher interest in student learning the higher the achievement of their learning results about the material of environmental balance. Students' interest in 
learning is directly influenced by the positive learning environment. This means that the more conducive learning environment that each student has, the higher his interest in learning about the material of environmental balance.

\section{References}

1. M. Syah, Learning Psychology, 63-152 (Jakarta: Raja Grafindo Persada, 2012)

2. H. Uno, Learning with PAILKEM Approaches, 138 (Jakarta: Bumi Aksara, 2012)

3. Djamarah, S. Basri, Learning Psychology, 13 (Jakarta: Rineka Cipta, 2002)

4. Miarsyah, M. Luvfiati, D. Mutiara, T. Ernawati, Natural Sciences for SMK and MAK Class XII, 62 (Jakarta :Erlangga, 2006)

5. Slameto, Learning and its Affecting Factors, 57 (Jakarta: RinekaCipta, 2012)

6. Djaali, Muljono, dan Pudji, Measurement in the education, 90 (Jakarta: PT Gramedia, 2008) 